\author{
Alicja Lumer ${ }^{*}$ \\ Uniwersytet Jagielloński
}

\title{
„ODCZAROWANE DZIECIŃSTWO” - NA PRZYKŁADZIE WYBRANYCH DZIEŁ LITERACKICH
}

\section{Abstract \\ Disenchanted childhood: On the example of selected literary works}

The essay is an attempt to disenchant the concept of childhood. Based on Lord of the Flies by William Golding and other literary works, the Author deals with the image of a child created as an innocent, incapable of evil, putting emphasis on the subjectivity of a child. The essay shows the important role of children in social life and discusses the theses of developmental psychology in which dominates the gradual nature of human development. It also emphasizes the significance of recognizing a child as a human being, an important, conscious person, capable of evil, hence deserving respect.

Key words: childhood, stereotyping, innocence, subjectivity, maturity

Człowieka, który patrzy w oczy dziecka, uderza przede wszystkim ich niewinność: owa przejmująca niezdolność do kłamstwa, do zakładania maski czy chęci bycia kimś innym, niż jest.

(de Mello 2019: 85)

\section{Szkodliwy stereotyp - zamiast wprowadzenia}

Dzieciństwo w powszechnej opinii to okres niewinności. Stan bycia dzieckiem w potocznym rozumieniu łączy się z bezbronnością, nieświadomością, niewiedzą, brakiem doświadczenia, a także brakiem odpowiedzialności bądź ograniczoną odpowiedzialnością za popełnione występki. Taki obraz dziecka podtrzymuje sztuka. Zarówno w literaturze, malarstwie, jak i w rzeźbie widoczne są tego przykłady. Sama postać cherubinka ukazywanego jako pulchne, uskrzydlone dziecko symbolizować miała czystość, świętość

* Studentka studiów I stopnia na kierunku socjologia, Instytut Socjologii UJ. 
i nieskazitelność istoty ukazanej jako mały aniołek. Podobny pogląd prezentuje Adam Mickiewicz. W Dziadach części II Guślarz, rozpoczynając obrzęd, przywołuje duchy lekkie - Józia i Rózię, którzy to nie doznali w życiu cierpienia, nie zgrzeszyli, a ich życie upłynęło na swawoli i zabawie. Obydwa przywołane przykłady kreślą nam obraz dzieciństwa jako raju na ziemi, a same dzieci przedstawiają jako niewinne.

\section{Proza czy rzeczywistość?}

Książką, która sprzeciwia się takiemu postrzeganiu rzeczywistości, jest Władca much Williama Goldinga (1967). Autor walczył w młodości pod banderą Royal Navy. Służba w wojsku odcisnęła silne piętno na jego osobowości, a co za tym idzie - i twórczości. Wpływ II wojny światowej na dzieła brytyjskiego pisarza objawia się w jego poglądach na temat mrocznej moralności ludzkiej oraz koncepcji upadku kultury stworzonej przez człowieka. Władca much jest tego najlepszym wyrazem.

Akcja dzieła toczy się w trakcie konfliktu nuklearnego. Powieść traktuje na temat chłopców, uczniów brytyjskich szkół, którzy w wyniku katastrofy lotniczej rozbijają się na wyspie. W wypadku giną wszyscy dorośli, co zmusza dzieci do organizacji swojego życia i zasad funkcjonowania na co dzień. Lektura ukazuje stopniową degradację, rozpad wartości i ujawnia barbarzyństwo, do jakiego zdolne są nawet dzieci - istoty, których nikt by o to nie posądził, co wywołuje szczególny szok i niedowierzanie u czytelnika. Zabieg zastosowany został przez Goldinga celowo. Obsadzenie w roli bohaterów dzieci miało dodatkowo rozwiać złudne wyobrażenia na temat dobrej natury człowieka. Pogląd autora o drzemiących w człowieku atawistycznych instynktach stoi w opozycji do założeń Jeana-Jacques’a Rousseau i naturalistów, którzy głosili, że powrót do natury i odcięcie od cywilizacji zagwarantuje życie w szczęściu i harmonii. Władca much kwestionował też poglądy stojące za innymi powieściami przygodowymi wydawanymi w tamtym okresie. Przedstawiały one człowieka, który w sytuacji granicznej nadal kieruje się europejskimi wartościami i zdolny jest do odtworzenia ich nawet w warunkach ekstremalnych. Taki wyidealizowany obraz bohatera cywilizowanego ukazywała Koralowa wyspa Roberta Michaela Ballantyne’a oraz Dwa lata wakacji Juliusza Verne’a.

\section{Dystans jako element władzy}

Celem Goldinga było skupienie się na ciemnej stronie moralności i naturze człowieka. Uważam, że obsadzenie w roli bohaterów chłopców stanowi wspaniały punkt wyjścia do przywrócenia dzieciom podmiotowości, „odczarowania” ich anielskiej natury i przełamania stereotypu, jaki się z tym wiąże. Gdy traktujemy dzieci z przeświadczeniem o ich inności, tworzymy sytuację dystansu. Pozycjonujemy wtedy siebie samych jako dorosłych na miejscu wyższym, bardziej uprzywilejowanym. Daje nam to poczucie władzy. Wydaje nam się, że to właśnie my, dojrzali, z większym doświadczeniem i świadomością zła 
możemy decydować i mieć rację. Tworząc taką barierę, żyjemy w iluzji, jakoby dzieciństwo było stanem z wyraźnym punktem przejścia, często utożsamianym z osiągnięciem 18. roku życia. Zapominamy o tym, że rozwój to stan dynamiczny i płynny, jak zauważa również Stephen King w książce To: „Dzieckiem nie przestawało się być w jednej chwili przy wtórze głośnego bum - jak odgłos pękającego balonu. Dzieciństwo wyciekało z ciebie jak powietrze z dziurawej opony" (King 2017: 657). Każdy człowiek ma inny bagaż doświadczeń i inne predyspozycje. Pamiętając o tym, możemy uświadomić sobie, że fazy rozwojowe nigdy nie będą zachodzić schematycznie czy planowo.

\section{Konsekwencje ulegania stereotypom}

Nierealistyczne i oderwane od rzeczywistości postrzeganie dzieciństwa jest źródłem problemów w mikroskali, takich jak brak empatii i komunikacji w rodzinie, wywodzących się z przeświadczenia o wyższości rodzica, jego wszechwiedzy na temat dobra syna bądź córki. Poważne skutki pojmowania dzieciństwa jako etapu z wyraźnym momentem końcowym widoczne są również w szerszej perspektywie. Brazylia jest krajem, w którym osoba do 18. roku życia uznawana jest za niezdolną do brania odpowiedzialności za swoje czyny. Implikuje to sytuację, w której większość czynów karalnych jest popełnianych przez nieletnich, zwłaszcza między 15. a 17. rokiem życia. Osoby te w większości „zatrudniane” są przez dorosłych, gdyż nie grozi im żadna kara. Dlatego ważne jest, jak widać także na tle politycznym, aby zaakceptować dzieciństwo jako fazę rozwojową człowieka, a nie uznawać je za zupełnie odrębną kategorię, tworząc kontrast i podkreślając różnice pomiędzy dzieckiem a człowiekiem. Pomocnym będzie też stwierdzenie przytoczone przez Martę Smagacz-Poziemską w jej książce Czy miasto jest niepotrzebne? (Nowe) przestrzenie życiowe młodych mieszkańców (2015). Autorka, prowadząc badania wśród młodzieży, przyjęła założenie, iż dziecko ma nie mniejsze, a po prostu inne kompetencje. Takie podejście umożliwiło dostosowanie ankiet do młodzieży, a zarazem uniknięcie ich infantylizacji.

\section{Lustrzane odbicie dorosłych}

Golding w swojej powieści przysłużył się do zniszczenia wyidealizowanego wizerunku dziecka. Umocnił jego pozycję poprzez ukazanie jego zdolności do czynienia zła. Chłopcy doprowadzili do śmieci Simona i Prosiaczka, krwawo walcząc o władzę i wprowadzając tyranię. Należy jednak zauważyć, że owi chłopcy są zdolni nie tylko do okrutnych czynów. Tuż po katastrofie podejmują próby zorganizowania życia swojej społeczności. Wybierają demokratycznie wodza, ustalają przydział obowiązków, daty zebrań. Świadczy to o ich zaradności, odpowiedzialności i racjonalności. Sytuacja jednak z biegiem czasu przybiera nieoczekiwany obrót. Dzieci swoim postępowaniem coraz bardziej przypominają dorosłych. Narrator w prześmiewczy sposób opisuje zebrania, którymi szczycą się chłopcy: 
Zebrania. Bardzo lubimy zebrania. Codziennie je robimy. Dwa razy na dzień. I gadamy [...]. Założę się, że gdybym w tej chwili zatrąbił, zaraz by przybiegli. Zaraz by się zrobili poważni i zaraz by któryś powiedział, że powinniśmy zbudować odrzutowiec albo łódź podwodną, albo telewizor. A jak zebranie się skończy, pięć minut popracują i rozlezą się albo pójdą polować (Golding 1967: 35).

Jest to aluzja do rządów demokratycznych, które w swojej ideowej wspaniałości często pozbawione są realizmu codziennego życia. Politycy chwalą system i swoje struktury, ale są to jedynie puste słowa, za którymi nie idą czyny. Na tej podstawie widoczny jest mechanizm kopiowania zachowań dorosłych przez dzieci, które ich naśladują.

Podobne odniesienie znajdujemy w książce do sytuacji II wojny światowej. Chłopcy są zdolni do destrukcji. Krwawo walczą o władzę, zapominając o wyznawanych wartościach. Zabijają „swoich”, rozprawiają się z przeciwnikami, dążą do konfliktu. Wskutek tego dochodzi do podpalenia wyspy. Stanowi to lustrzane odbicie okrutnej równoległej rzeczywistości „dorosłych” prowadzących walki i wojny w „dorosłym” świecie. W ten sposób brytyjski autor burzy mury w głowach czytelników, niejako zdejmuje aureole z głów dzieci. Szokując, przedstawia brutalną rzeczywistość, w której dziecko jako zdolne do czynienia zła nabywa podmiotowość, zwraca na siebie uwagę dorosłych. Zasługuje ono na szacunek, gdyż również w nim drzemie nieokiełznana siła i instynkty. Taki obraz podkreśla konieczność brania pod uwagę dziecka, jego opinii, spostrzeżeń i potrzeb. Golding, jako obserwator upadku cywilizacji europejskiej, zwraca uwagę, że normy i wzorce mają charakter porządkujący i są potrzebne, jednakże muszą one iść w parze z zachowaniami i działaniami, jakie podejmuje człowiek, gdyż w innym wypadku jest to obłuda. Prawdziwe zdaje się przysłowie: „Kto z kim przystaje, takim się staje”. Wymaga to od dorosłych życia w zgodzie z pozytywnymi wzorcami, które dzieci mogłyby naśladować. Stąd też rolą dorosłego jest stanie na straży wartości, wprowadzanie młodego człowieka w świat i odgrywanie roli przewodnika, mentora, opiekuna. Relacja ta powinna opierać się na obopólnym szacunku.

\section{Potęga świadomości i odpowiedzialności}

Dziecko jako człowiek o innych kompetencjach powinno mieć prawo do brania czynnego udziału w życiu społecznym, a tym samym do realizowania swojego potencjału i rozwijania swoich często ukrytych zdolności. Obecność dzieci w świecie widoczna jest ostatnio w sferze polityki, na którą mają ogromny wpływ. Przykładem z ostatniego roku jest Greta Thunberg, siedemnastolatka, która przez publiczne zabranie głosu w debacie na temat ekologii poruszyła serca osób na całym świecie ze względu na swój emocjonalny stosunek do sprawy i zajęcie się tak poważnym „,jak na jej wiek” tematem. Inną młodą osobą, która również została zauważona przez swoją działalność na rzecz uciśnionych, jest Malala Yousafzai. Nastolatka została wyróżniona Pokojową Nagrodą Nobla „za walkę z ciemiężeniem dzieci i młodych ludzi oraz o prawo wszystkich dzieci do edukacji”. 
Waga oddziaływania świata dzieci i dorosłych na siebie widoczna jest też w zjawisku parentyfikacji. Jest to sytuacja, kiedy dziecko stara się przejąć rolę dorosłego w domu i rodzinie, mimo że wykracza to ponad jego siły fizyczne i psychiczne. I choć zjawisko to ma wydźwięk negatywny i określane jest jako niezdrowy wzorzec relacji z rodzicem agresywnym, nieobecnym, uzależnionym czy niedojrzałym, to ukazuje ono siłę dziecka, uwidacznia jego zdolność do poświęcenia się i przyjęcia odpowiedzialności. Sytuację taką często określa się mianem „dramatu dzielnych dzieci”. Badacze wskazują, że parentyfikacja może być też pozytywna i widoczna jest zwłaszcza u najstarszych dzieci w rodzeństwie, u których poziom odpowiedzialności i poczucia sprawczości wzrasta. Przypadki te są jednak rzadkie, a granica wkroczenia w relacje o negatywnych implikacjach jest bardzo płynna. Pomimo to samo zjawisko wskazuje na siłę, jaką obdarzone są dzieci. Są one zdolne nie tylko do zła, co ukazał Golding, ale również do bezinteresownego poświęcenia i oddania. Potrafią przyjąć na siebie ciężar, nie zważając na konsekwencje.

Jak widać, dziecko, wbrew częstym błędnym mniemaniom, potrafi diagnozować problem i pomagać - na tyle, na ile jest w stanie i na ile pozwala mu zgromadzona wiedza i doświadczenie. Jak trafnie ujął to jeden z najwybitniejszych pedagogów Janusz Korczak (2012: 27): „Dziecko nie jest głupie; głupców wśród nich nie więcej niż wśród dorosłych”.

Golding definitywnie rozprawia się z idealistyczną wizją natury ludzkiej. Grzmi o tym, że zło tkwi w człowieku. Dodaje, że za człowieka uznaje się też dziecko, któremu nie można odbierać godności i szacunku, żyjąc w iluzji i przeświadczeniu o jego nieskazitelności. Jeden z bohaterów powieści, Ralph, płacze nad „kresem niewinności i ciemnotą ludzkich serc" (Golding 1967: 153), bo sytuacja, w której znaleźli się chłopcy, zmusza do refleksji i zmiany utartych schematów myślenia.

\section{Bibliografia}

Golding W. (1967). Władca much. Spółdzielnia Wydawnicza „Czytelnik”, Lublin. King S. (2017). To. Albatros. Warszawa.

Korczak J. (2012). Prawo dziecka do szacunku. Wydawnictwo Rzecznik Praw Dziecka, Warszawa. Mello A. de (2019). Wezwanie do miłości. Wydawnictwo Zysk i S-ka, Poznań.

Smagacz-Poziemska M. (2015). Czy miasto jest niepotrzebne? (Nowe) przestrzenie życiowe młodych mieszkańców. Wydawnictwo Naukowe Scholar, Warszawa. 